\title{
PENGARUH KONSENTRASI MALTODEKSTRIN PADA ADONAN BEKU TINGGI PROTEIN TERHADAP KARAKTERISTIK ROTI
}

\author{
[The Effect of Maltodextrin Concentration in High Protein Frozen Dough \\ on Bread Characteristics]
}

\section{Desiana Nuriza Putri ${ }^{\star}$ Okta Pringga Pakpahan, Damat, Ari Rizki Yuspita Ningrum, dan Erika Novena Santoso}

Program Studi Teknologi Pangan, Fakultas Pertanian-Peternakan, Universitas Muhammadiyah Malang, Malang

Diterima 22 Juni 2020 / Disetujui 10 November 2021

\begin{abstract}
The maltodextrin in frozen dough functions as the cryoprotectant to keep the structure of dough and yeast viability during freezing. This study investigated the optimum maltodextrin concentration in the highprotein frozen dough to obtain the best characteristics of sweet bread. The experimental design was a simple, completely randomized design (CRD) with one factor, i.e., maltodextrin concentrations of 0 , 1 , and $2 \% \mathrm{w} / \mathrm{w}$. The experiment was done in triplicates with $0 \%$ maltodextrin as the control. During ten days of frozen storage, it was found that the addition of maltodextrin significantly affected the number of viable yeast after freezing. Furthermore, the addition of $2 \%$ maltodextrin produces the best bread characteristics. Furthermore, the addition of maltodextrin to the frozen dough also protects the water content during proofing which was shown by loaf volume $85.80 \%$ and water content of $15.30 \%$. Furthermore, yeast viability and the gluten content in bread profoundly impacted the optimum elasticity crumb firmness value $2.00 \mathrm{~N} / \mathrm{mm}^{2}$.
\end{abstract}

Keywords: cryoprotectant, frozen dough, maltodextrin, sweet bread

\begin{abstract}
ABSTRAK
Maltodekstrin pada adonan berfungsi sebagai krioprotektan untuk melindungi struktur adonan dan viabilitas ragi selama pembekuan. Penelitian ini bertujuan untuk mengkaji konsentrasi maltodekstrin optimum dalam adonan protein tinggi untuk menghasilkan karakteristik roti manis terbaik. Rancangan percobaan yang digunakan adalah Rancangan Acak Lengkap (RAL) sederhana dengan satu factor yaitu konsentrasi maltodekstrin $(0,1$ dan $2 \%$ b/b). Setiap perlakuan diulang tiga kali dan perlakuan maltodekstrin $0 \%$ ditetapkan sebagai control. Selama sepuluh hari penyimpanan beku, didapatkan hasil bahwa penambahan maltodekstrin berpengaruh nyata terhadap jumlah khamir yang hidup setelah pembekuan. Penambahan maltodekstrin $2 \%$ menghasilkan karakteristik roti terbaik. Selain itu, penambahan maltodekstrin pada adonan beku juga mempertahankan kadar air saat proofing time ditunjukkan dari volume roti $85,80 \%$ dan kadar air $15,30 \%$. Selanjutnya, viabilitas ragi dan kandungan gluten dalam roti sangat mempengaruhi nilai elastisitas remah yang optimum $2,00 \mathrm{~N} / \mathrm{mm}^{2}$.
\end{abstract}

Kata kunci: adonan beku, krioprotektan, maltodekstrin, roti manis

\section{PENDAHULUAN}

Roti manis menjadi salah satu jenis roti yang digemari masyarakat Indonesia, hal ini terlihat dari peningkatan konsumsi roti manis perkapita tahun 2015 berkisar $0,376 \mathrm{~kg} / \mathrm{minggu}$ menjadi 0,548 $\mathrm{kg} /$ minggu pada tahun 2019 (BPS, 2020). Tingginya potensi permintaan pasar terhadap roti manis

*Penulis Korespondensi:

E-mail: desiana@umm.ac.id menuntut perusahaan untuk meningkatkan efisiensi produksi yang dapat mempertahankan standar mutu produk. Pembuatan roti manis dengan teknologi adonan beku (frozen dough) mampu meningkatkan efisiensi karena tidak membutuhkan banyak tenaga kerja dan mudah diolah menjadi fresh bread sehingga mampu menghasilkan produk dengan mutu yang homogen di setiap tempat. Selain itu, adonan beku menawarkan beberapa keuntungan seperti penurunan biaya produksi karena proses produksi yang terpusat, masa simpan lebih lama karena 
disimpan pada suhu beku dan distribusi adonan skala besar yang lebih mudah karena pendistribusian sudah dalam bentuk adonan beku bukan bahan mentah (de la Cruz-Gavia et al., 2018).

Senyawa krioprotektan digunakan pada makanan untuk mengontrol nukleasi air tidak berubah menjadi bentuk es didalam struktur makanan (Seetapan et al., 2015). Pada pembuatan frozen dough, senyawa krioprotektan ditambahkan untuk melindungi ragi dan mempertahankan kadar air selama penyimpanan pada suhu beku. Hal ini terjadi dengan mekanisme krioprotektan melindungi ikatan matriks gluten yang mencegah ekskresi air keluar dari sel ragi (Momose et al., 2010). Maity et al. (2011) dalam studinya menjelaskan bahwa penambahan senyawa krioprotektan berperan dalam proses penahanan air dan viskoelastik untuk melindungi struktur produk makanan saat penyimpanan suhu beku. Senyawa krioprotektan yang sering digunakan pada negara di kawasan Asia adalah jenis maltodekstrin (Abd-El-Khalek, 2020). Sze-Yin dan Lai-Hoong (2013) pada penelitiannya telah membuktikan bahwa maltodekstrin dengan konsentrasi $2 \%$ dapat mengurangi tingkat kerusakan ragi pada adonan ketika pembekuan. Namun, hal tersebut masih memiliki permasalahan dengan adonan yang mengunakan tepung protein lebih dari 35\% $(>4,84 \mathrm{~g})$ dari berat adonan yang disebabkan oleh kristal es. Selama penyimpanan beku, kelebihan protein mampu menggumpalkan amilosa dengan cepat sehingga terjadi interaksi berlebihan antara pati dan gluten. Kondisi ini menyebabkan kristalisasi pada crumb (Witczak et al., 2010).

Lebih lanjut, Leray et al. (2010) menjelaskan kristal es akan berpengaruh ketika proses thawing yang berdampak pada penurunan retensi gas selama fermentasi. Oleh sebab itu, penelitian ini bertujuan untuk menganalisis pengaruh penambahan maltodekstrin sebagai krioprotektan (1-2\%) terhadap karakteristik roti manis.

\section{BAHAN DAN METODE}

\section{Bahan}

Tepung gandum berprotein tinggi (13\%) (Merck, Indonesia), tepung gandum berprotein sedang (11-12,5\%) (PT Indofood Sukses Makmur Tbk, Indonesia), gula, garam, emulsifier, maltodekstrin DE 16 (Lihua Starch, Cina) dengan tingkat kemurnian $100 \%$ yang diperoleh dari Laboratorium Ilmu dan Teknologi Pangan, Universitas Muhammadiyah Malang, ragi instan, telur ayam ras, mentega, margarin, susu skim, aquadest dingin, Bahan kimia yang digunakan adalah $\mathrm{NaOH}$ (Merck, Jerman), $\mathrm{H}_{2} \mathrm{SO}_{4}$ (Merck, Jerman) dan aquades.

\section{Pembuatan roti manis (Damat et al., 2017 dengan modifikasi)}

Formula roti manis terdiri dari empat level variabel bebas yaitu roti tanpa penambahan maltodekstrin $(0 \%)$, penambahan $1 \%$ maltodekstrin, penambahan $2 \%$ maltodekstrin dan tanpa pembekuan (Tabel 1). Prosedur pembuatan roti manis yaitu dengan mencampurkan bahan kering (tepung terigu, gula, ragi), telur dan air kemudian diaduk dengan dough mixer (kecepatan rendah, \pm 10 menit) kemudian ditambahkan garam dan mentega diaduk dengan kecepatan tinggi ( \pm 20 menit). Adonan kemudian dibagi menjadi beberapa bagian (dividing) dengan berat $20 \mathrm{~g}$ dan dibulatkan (moulding).

Adonan dimasukkan ke dalam loyang plastik yang dilanjutkan ditutup dengan plastik wrap dilanjutkan dengan pembekuan pada chest freezer (Electrolux ECM2100 WA-XE, Cina) dengan suhu $-20^{\circ} \mathrm{C}$, dan disimpan selama 10 hari. Adonan di thawing menggunakan proofer (Getra FX-15J, Cina) $\left(30^{\circ} \mathrm{C}, 1\right.$ jam) dan dilanjutkan fermentasi menggunakan proofer $\left(40^{\circ} \mathrm{C}, 1 \mathrm{jam}\right)$ dengan kelembapan relatif (RH) $80-85 \%$.

Tabel 1. Formulasi roti manis metode frozen dough

\begin{tabular}{lcccc}
\multicolumn{1}{c}{ Komposisi $(\mathrm{g})$} & Kontrol 1 & 1 Maltodekstrin & 2 Maltodekstrin & Kontrol 2 \\
\hline Terigu protein tinggi & 80 & 80 & 80 & 80 \\
Terigu protein sedang & 20 & 20 & 20 & 20 \\
Air es & 45 & 45 & 45 & 45 \\
Margarin & 0 & 0 & 0 & 0 \\
Mentega & 10 & 10 & 10 & 10 \\
Telur & 20 & 20 & 20 & 20 \\
Susu bubuk & 20 & 20 & 20 & 20 \\
Gula pasir & 20 & 20 & 20 & 20 \\
emulsifier & 0,5 & 0,5 & 0,5 & 0,5 \\
Ragi Instant & 2 & 2 & 2 & 2 \\
Garam & 1 & 1 & 1 & 1 \\
Maltodekstrin & 0 & 1 & 2 & 0 \\
Proses Pembekuan & Ya & Ya & Ya & Tidak \\
\hline
\end{tabular}


Tahap terakhir adalah pengovenan (RFL-36, Cina) $\left(150^{\circ} \mathrm{C}, 15\right.$ menit) hingga warna roti manis menjadi kuning kecokelatan. Sampel dianalisis setelah pendinginan selama satu jam. Pengambilan sampel untuk dianalisis jumlah ragi yang hidup, sifat pengembangan roti, volume spesifik, kekerasan, kadar air, kadar abu dan sifat organoleptik dilakukan pada hari ke-0 (sebelum pembekuan) dan penyimpanan beku hari ke-10.

\section{Hardness analysis (Mandala et al., 2007)}

Roti manis dipotong dengan bentuk kubus dengan ukuran $2 \times 2 \times 2 \mathrm{~cm}$ lalu sampel ditekan dengan menggunakan silinder probe dengan diameter 10 mm menggunakan alat Texture Analyzer (Shimadzu EZ-100 Test model SM-500N-168, Jepang), dengan prinsip daya tekan pada alat atau mampunya bahan untuk kembali ke posisi semula setelah tekanan dihilangkan (satuan $\mathrm{N} / \mathrm{mm}^{2}$ ).

\section{Elastisitas (Anggraeni et al., 2017)}

Prosedur pengujian Texture Analyze yaitu knife probe $\mathrm{P} / 2$ dan meja sampel HDP/90 dipasang. Model texture analyzer diatur sebagai measure force in compression. Sampel roti diukur diameter dan ketebalannya lalu diletakkan pada meja sampel. Probe pemotong menyentuh roti hingga terjadi fracture dan kembali ke posisi semula.

\section{Uji volume pengembangan (Imami dan Sutrisno, 2018)}

Volume pengembangan dihitung dengan cara membagi volume roti dengan volume adonan, volume pengembangan dihitung dengan satuan persen (\%). Volume dihitung dengan rumus setengah bola $\left(1 / 2\left(4 / 3 \pi r^{3}\right)\right)$. Lebar bawah roti manis diukur di diameter dengan jangka sorong dan rata-rata dicatat.

\section{Uji keseragaman pori (crumb) roti manis}

Sampel adonan panggang diiris secara vertikal dan gambar relatifnya diambil menggunakan kamera handphone VIVO tipe V5s dengan resolusi Super $\mathrm{HD}$ dan diamati lubang pori yang terlihat.

\section{Uji viabilitas ragi (Noroul et al., 2013)}

Peralatan pengujian, aquades dan media PDA disterilisasi menggunakan autoklaf $\left(121^{\circ} \mathrm{C}, 15\right.$ menit). Sampel sebanyak $1 \mathrm{~g}$ diencerkan hingga pengenceran $10^{-4}$ di dalam tabung reaksi berisi $9 \mathrm{~mL}$ akuades. Isolat yeast pada pengenceran keempat sebanyak $1 \mathrm{~mL}$, dipindahkan ke media PDA. Kemudian diinkubasi $\left(35^{\circ} \mathrm{C}, 72\right.$ jam). Ragi yang tumbuh dihitung jumlahnya menggunakan metode perhitungan total plate count.

\section{Uji organoleptik (Pusuma et al., 2018)}

Pengujian organoleptik dilakukan dengan metode hedonik (kesukaan) meliputi kesukaan terhadap rasa, tekstur dan kesukaan secara keseluruhan. Dalam pengujian ini, panelis memberikan penilaian berdasarkan tingkat kesukaan. Skor yang digunakan adalah 5 (sangat suka), 4 (suka), 3 (cukup suka), 2 (tidak suka), 1 (sangat tidak suka). Pengujian organoleptik dilakukan oleh 30 orang panelis (19 wanita, 11 laki-laki) tidak terlatih (umur 19-22 tahun).

\section{Analisis statistik}

Rancangan percobaan penelitian ini adalah rancangan acak lengkap sederhana (RAL) dengan faktor perlakuan yaitu penambahan maltodekstrin $(0$, 1 , dan $2 \% \mathrm{~b} / \mathrm{b}$ ) dengan tiga ulangan, $0 \%$ sebagai kontrol (tanpa penambahan maltodekstrin). Analisis karakteristik roti dilakukan pada sampel tanpa penyimpan beku dan setelah 10 hari penyimpanan beku. Hasil pengujian karakteristik roti manis dianalisis secara statistik menggunakan perangkat lunak SPSS 20 kemudian dilanjutkan dengan uji lanjut metode Duncan Multiple Range Test (DMRT) pada taraf kepercayaan $5 \%$.

\section{HASIL DAN PEMBAHASAN}

\section{Bahan baku maltodekstrin}

Analisis bahan baku bertujuan untuk mengetahui kandungan kimia suatu bahan sebelum ditambahkan dalam pembuatan adonan beku sehingga dapat diketahui pengaruh yang dapat ditimbulkan dari penggunaan bahan terhadap karakteristik fisikokimia produk roti manis. Spesifikasi maltodekstrin terdapat pada Tabel 2. Maltodekstrin merupakan produk hidrolisis pati yang memiliki nilai DE sesuai dengan berat molekul. Nilai DE yang lebih tinggi menunjukkan derajat hidrolisis yang lebih tinggi dan sebagian besar terdiri dari polimer glukosa dengan berat molekul lebih kecil, seperti glukosa dan oligosakarida (Harnkarnsujarit et al., 2012). Berdasarkan hasil analisis, spesifikasi mutu maltodektsrin berwarna putih dengan kandungan gula reduksi sebesar $7,61 \%$. Pada proses hidrolisis pati, ketika ukuran molekul menurun, jumlah gula reduksi dan DE meningkat, dan diikuti oleh peningkatan reaksi Maillard (Honary dan Zahir, 2013).

Tabel 2. Spesifikasi mutu maltodekstrin

\begin{tabular}{lc}
\hline \multicolumn{1}{c}{ Parameter } & Maltodekstrin Penelitian \\
\hline Kadar air & $7,57 \%$ \\
Gula reduksi & $7,61 \%$ \\
Warna & Putih \\
Rasa & Hambar \\
DE & 16 \\
\hline
\end{tabular}


Gula reduksi dipengaruhi oleh konsentrasi pati dan enzim, semakin tinggi konsentrasi pati dan enzim semakin tinggi gula reduksi. Nilai DE Dextrose Euquivalent (DE) maltodekstrin menggambarkan kandungan gula pereduksi. Maltodekstrin dengan nilai DE tinggi mengandung molekul dengan berat molekul lebih kecil dari maltodekstrin dengan nilai DE rendah. Maltodekstrin DE tinggi lebih mudah menyerap air dan menghasilkan proses degradasi (Yamashita et al., 2017).

\section{Volume pengembangan roti manis}

Penambahan maltodekstrin $2 \%$ efektif dalam mempertahankan volume pengembangan roti manis setelah pembekuan sepuluh hari, sedangkan perlakuan tanpa penambahan maltodekstrin terjadi penurunan sebesar 58\%. Penambahan maltodekstrin dapat meningkatkan volume pengembangan pada roti manis dengan perlakuan pembekuan. Sampel tanpa pembekuan memiliki volume pengembangan lebih besar yaitu 187\%, sedangkan volume pengembangan sampel dengan perlakuan maltrodekstrin berkisar $78-160 \%$, volume pengembangan turun secara signifikan selama penyimpanan beku $(P<0,05)$. Volume pengembangan sampel tanpa penambahan maltodekstrin menunjukkan penurunan tajam selama 10 hari penyimpanan. Roti manis dengan volume pengembangan tertinggi pada hari ke 0 yaitu pada perlakuan tanpa pembekuan diikuti dengan perlakuan maltodekstrin $0 \%$ berturut-turut yaitu sebesar 187,08 dan 167,81\% (Tabel 3). Volume pengembangan tertinggi pada hari ke 10 yaitu pada perlakuan tanpa pembekuan sebesar 187,08\% diikuti dengan perlakuan maltodekstrin $2 \%$ sebesar $85,80 \%$. Sejalan dengan hasil penelitian ini, penelitian Chandralekha et al. (2016) yang mempelajari pengaruh bahan pembawa yang berbeda untuk melindungi sel Saccharomyces cerevisiae selama proses spray drying dan freeze drying, hasil penelitian menyimpulkan bahwa sel-sel ragi menunjukkan perlindungan yang lebih tinggi ( $85 \%$ sel hidup) selama waktu penyimpanan ketika menggunakan kombinasi pati jagung dan maltodekstrin sebagai bahan pembawa.

Hasil penelitian lain Sze-Yin dan Lai-Hoong (2013) menyatakan bahwa campuran antara treha- lose $0,1 \%$ dan maltodekstrin 1 atau $2 \%$ dapat meningkatkan volume spesifik Chinese Steamed Bread yang terbuat dari adonan beku dibandingkan dengan perlakuan penambahan trehalosa sebesar 0,2\%. Menurut Nopianti et al. (2012) krioprotektan berperan mencegah protein terdenaturasi selama penyimpanan beku. Menurut Kondakci et al. (2015) pembekuan adonan dapat menurunkan volume pengembangan karena terjadi penurunan kekuatan jaringan gluten didalam adonan selama penyimpanan beku yang dapat menyebabkan penurunan retensi gas dengan dua kemungkinan mekanisme, pertama, ketersediaan molekul karbohidrat yang dapat difermentasi oleh ragi (Ghoshal et al., 2016). Kedua, selama proses pemanggangan glukan dengan derajat polimerasasi yang tinggi memberikan pengaruh negatif pada struktur adonan (Eduardo et al., 2016).

\section{Tekstur roti manis}

Penambahan maltodekstrin berpengaruh tidak signifikan terhadap kekerasan roti $(P>0,05)$ dan tidak terjadi penurunan tekstur yang signifikan setelah pembekuan sepuluh hari (Tabel 4), hal ini dikarenakan maltodekstrin dapat bekerja melindungi ragi sehingga tekstur roti bisa dipertahankan selama penyimpanan beku. Hasil ini berbeda dengan penelitian Topaloglu (2015) yang menyatakan bahwa setelah 7 hari penyimpanan produk, kekerasan meningkat sekitar $67 \%$ yang disebabkan oleh peningkatan kehilangan kandungan air. Hasil penelitian Sze-Yin dan Lai-Hoong (2013) menunjukkan bahwa penyimpanan beku dapat meningkatkan tekstur pada Chinese Steamed Bread dari adonan beku dengan penambahan krioprotektan dari campuran trehalosa dan maltodekstrin. Penambahan krioprotektan trehalosa dan maltodekstrin dengan konsentrasi 0,2 dan $2 \%$ dengan freezing time selama 5 bulan menghasilkan tekstur roti kukus dari adonan beku yang paling lembut atau tekstur yang relatif lebih rendah. Penambahan krioprotektan yang sesuai dan optimal sangat penting untuk mengontrol pelelehan es dan rekristalisasi pada adonan selama penyimpanan beku (Sze-Yin dan Lai-Hoong, 2013) dan penambahan krioprotektan yang terlalu banyak dapat merusak tekstur roti.

Tabel 3. Volume pengembangan roti manis di awal dan akhir pembekuan

\begin{tabular}{lccc}
\hline \multirow{2}{*}{ Perlakuan } & \multicolumn{3}{c}{ Volume Pengembangan (\%) } \\
\cline { 2 - 4 } & Hari ke 0 & Hari ke 10 & Selisih $(\%)$ \\
\hline Maltodekstrin 0\% & $167,81 \pm 10,91^{\mathrm{b}}$ & $68,20 \pm 23,6^{\mathrm{a}}$ & $58^{\mathrm{b}}$ \\
Maltodekstrin 1\% & $127,70 \pm 59,13^{\mathrm{ab}}$ & $75,01 \pm 12,15^{\mathrm{a}}$ & $0^{\mathrm{ab}}$ \\
Maltodekstrin 2\% & $78,23 \pm 13,42^{\mathrm{a}}$ & $85,80 \pm 15,09^{\mathrm{a}}$ & $0^{\mathrm{a}}$ \\
Tanpa pembekuan & $187,08 \pm 26,33^{\mathrm{b}}$ & $187,08 \pm 26,33^{\mathrm{b}}$ & $0^{\mathrm{a}}$ \\
\hline
\end{tabular}

Keterangan: Data merupakan hasil rata-rata dari 3 ulangan dan angka diiukuti oleh huruf abjad yang berbeda menunjukkan perbedaan nyata berdasarkan uji DMRT $\alpha=5 \%$ 
Tabel 4. Tekstur roti manis di awal dan akhir pembekuan

\begin{tabular}{lccc}
\hline \multirow{2}{*}{ Perlakuan } & \multicolumn{3}{c}{ Tekstur $\left(\mathrm{N} / \mathrm{mm}^{2}\right)$} \\
\cline { 2 - 4 } & Hari ke 0 & Hari ke 10 & Selisih \\
\hline Maltodekstrin 0\% & $0,46 \pm 0,12^{\mathrm{a}}$ & $0,40 \pm 0,09^{\mathrm{a}}$ & $0,07 \pm 0,08^{\mathrm{a}}$ \\
Maltodekstrin 1\% & $0,51 \pm 0,12^{\mathrm{a}}$ & $0,80 \pm 0,32^{\mathrm{a}}$ & $-0,29 \pm 0.39^{\mathrm{a}}$ \\
Maltodekstrin 2\% & $0,70 \pm 0,07^{\mathrm{a}}$ & $0,81 \pm 0,03^{\mathrm{a}}$ & $-0,11 \pm 0,06^{\mathrm{a}}$ \\
Tanpa pembekuan & $5,11 \pm 1,03^{\mathrm{b}}$ & $5,11 \pm 1,03^{\mathrm{b}}$ & $0,07 \pm 0^{\mathrm{a}}$ \\
\hline
\end{tabular}

Keterangan: Data merupakan hasil rata-rata dari 3 ulangan dan angka diiukuti oleh huruf abjad yang berbeda menunjukkan perbedaan nyata berdasarkan uji DMRT $\alpha=5 \%$

\section{Elastisitas roti manis}

Penambahan maltodekstrin $1 \%$ efektif untuk mempertahankan elastisitas roti dibandingkan tanpa penambahan maltodekstrin setelah pembekuan sepuluh hari. Penambahan maltodekstrin berpengaruh nyata terhadap elastisitas roti $(P<0,05)$. Elastisitas roti manis mengalami penurunan setelah 10 hari pembekuan (Tabel 5). Elastisitas roti menurun sebagai akibat molekul gluten yang terdegradasi atau dehidrasi selama penyimpanan beku. Hasil ini didukung oleh Kohajdová et al. (2009) yang menerangkan bahwa dalam produk bakery, maltodekstrin berfungsi untuk memperlambat staling, meningkatkan kualitasproduk segar, mencegah pertumbuhan kristal es dalam produk selama penyimpanan beku dan mampu meningkatkan stabilitas beku-cair.

Gliadin dalam gluten berperan sebagai perekat sehingga adonan menjadi elastis, sedangkan glutenin berfungsi untuk menahan gas $\mathrm{CO}_{2}$ yang dihasilkan oleh ragi sehingga adonan dapat mengembang dan membentuk pori pori, selain itu glutenin mampu mempertahankan adonan agar tetap kokoh (Ayustaningwarno, 2014). Hasil penelitian dengan penambahan maltodekstrin 1\% menghasilkan penurunan elastisitas terkecil yaitu sebesar $0,10 \pm 0,13$ Penambahan krioprotektan yang sesuai dan optimal sangat penting untuk mengontrol pelelehan es dan rekristalisasi pada adonan selama penyimpanan beku dan penambahan krioprotektan yang terlalu banyak dapat merusak tekstur roti (Sze-Yin dan LaiHoong, 2013). Menurut Kohajdova et al. (2009) penambahan maltodekstrin dapat mencegah pertumbuhan kristal es sehingga kerusakan gluten dapat dicegah. Penambahan krioprotektan yang sesuai dan optimal sangat penting untuk mengontrol pelelehan es dan rekristalisasi pada adonan selama penyimpanan beku (Sze-Yin dan Lai-Hoong, 2013) dan penambahan krioprotektan yang terlalu banyak dapat merusak tekstur roti.

\section{Kenampakan pori (crumb)}

Kenampakan crumb pada roti manis setelah penyimpanan beku selama 10 hari secara kualitatif (Gambar 1) yaitu porositas roti tanpa penambahan maltodekstrin dan $2 \%$ maltodekstrin tidak menunjukkan perbedaan yang signifikan, roti dengan formulasi $1 \%$ maltodekstrin menghasilkan pori yang lebih seragam dari pada roti yang lain, hal ini sesuai dengan Arendt et al. (2011) yang menyatakan bahwa adonan yang dapat mempertahankan $\mathrm{CO}_{2}$ menghasilkan roti yang lebih berpori. Hal ini disebabkan oleh maltodekstrin yang dapat melindungi ragi dan gluten saat proses pembekuan sehingga gas $\mathrm{CO}_{2}$ yang dihasilkan ragi dapat dipertahankan. Menurut Phimolsiripol et al. (2012) konsumen lebih menyukai roti dengan kenampakan pori yang seragam dan berukuran sedang hingga besar $(4,21 \pm 0,69$ $\mathrm{mm})$. Kenampakan crumb dipengaruhi oleh komposisi bahan seperti jenis tepung terigu yang digunakan dan penambahan lemak (mentega atau shortening), emulsifier, adanya penambahan hidrokoloid, serta kadar abu dan aktivitas metabolisme ragi (Rathnayake et al., 2018).

Penambahan maltodekstrin melindungi kerusakan protein (gluten) dari kristal es akibat pembekuan, perlindungan tersebut berupa pengikatan air sehingga air yang dibutuhkan protein untuk menghasilkan struktur crumb yang seragam. Semakin meningkat ukuran kristal es memberikan efek signifikan terhadap penurunan kekuatan jaringan gluten. Penambahan maltodekstrin sebesar 1\% menghasilkan crumb yang memiliki pori lebih besar dan seragam, sedangkan roti tanpa maltodekstrin memiliki kenampakan crumb roti manis yang dihasilkan lebih terlihat halus dan memiliki pori yang lebih seragam namun kecil-kecil. Roti dengan crumb kecil mengindikasikan bahwa roti tidak mengembang sempurna atau bantat.

\section{Kadar air roti manis}

Penambahan maltodekstrin berpengaruh signifikan terhadap kadar air roti manis (Tabel 6). Penurunan kadar air roti tertinggi setelah pembekuan yaitu pada perlakuan penambahan maltodekstrin $1 \%$ sebesar $2,55 \%$. Hal ini karena maltodekstrin mengikat air bebas dalam adonan untuk membentuk jaringan, sehingga penambahan maltodekstrin lebih tinggi mengakibatkan penurunan kadar air adonan, jaringan lebih padat dan struktur roti lebih kaku. Topaloglu (2015) menyatakan bahwa peningkatan jumlah maltodekstrin yang ditambahkan dalam adonan menyebabkan penurunan kadar air pada adonan dan memberikan hasil kadar air roti sekitar 18 dan $16 \%$ setelah pembekuan adonan pada hari ke 0 dan ke-10. 


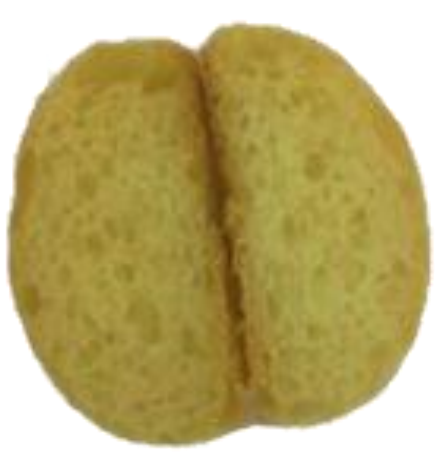

A

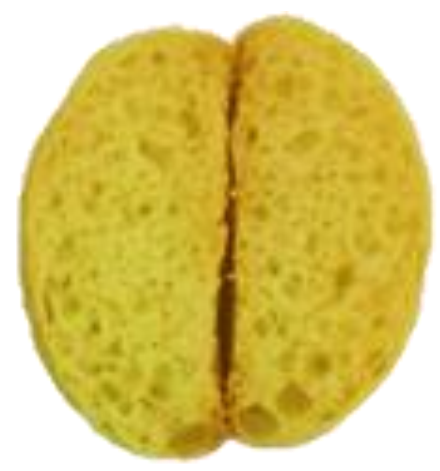

B

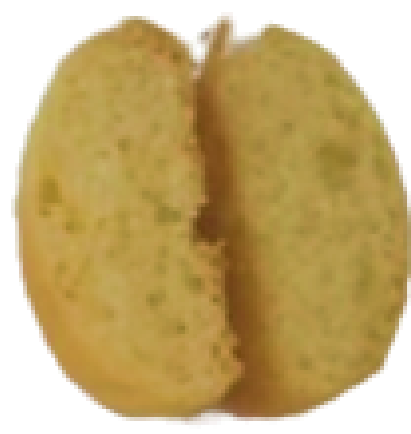

C

Keterangan $\mathrm{A}=$ tanpa penambahan maltodekstrin; $\mathrm{B}=$ penambahan $1 \%$ maltodekstrin; $\mathrm{C}=$ penambahan $2 \%$ maltodekstrin

Gambar 1. Kenampakan crumb roti manis

Tabel 5. Elastisitas roti manis di awal dan akhir pembekuan

\begin{tabular}{lccc}
\hline \multirow{2}{*}{ Perlakuan } & \multicolumn{3}{c}{ Elastisitas $\left(\mathrm{N} / \mathrm{mm}^{2}\right)$} \\
\cline { 2 - 4 } & Hari ke 0 & Hari ke 10 & $0,27 \pm 0,05^{\mathrm{ab}}$ \\
\hline Maltodekstrin 0\% & $1,99 \pm 0,25^{\mathrm{a}}$ & $1,72 \pm 0,26^{\mathrm{a}}$ & $0,10 \pm 0,13^{\mathrm{ab}}$ \\
Maltodekstrin 1\% & $2,81 \pm 0,71^{\mathrm{a}}$ & $2,71 \pm 0,63^{\mathrm{b}}$ & $0,60 \pm 0,57^{\mathrm{b}}$ \\
Maltodekstrin 2\% & $2,60 \pm 0,38^{\mathrm{a}}$ & $2,00 \pm 0,20^{\mathrm{ab}}$ & $0,00 \pm 0^{\mathrm{a}}$ \\
Tanpa pembekuan & $13,35 \pm 0,56^{\mathrm{b}}$ & $13,35 \pm 0,56^{\mathrm{c}}$ & $0^{\mathrm{a}}$ \\
\hline
\end{tabular}

Keterangan: Data merupakan hasil rata-rata dari 3 ulangan dan angka diiukuti oleh huruf abjad yang berbeda menunjukkan perbedaan nyata berdasarkan uji DMRT $\alpha=5 \%$

Tabel 6. Kadar air roti manis di awal dan akhir pembekuan

\begin{tabular}{lccc}
\hline \multirow{2}{*}{ Perlakuan } & \multicolumn{3}{c}{ Kadar Air (\%) } \\
\cline { 2 - 4 } & Hari ke 0 & Hari ke 10 & Selisih \\
\hline Maltodekstrin0\% & $15,41 \pm 0,144^{\mathrm{a}}$ & $15,08 \pm 0,56^{\mathrm{a}}$ & $0,33 \pm 0,49^{\mathrm{a}}$ \\
Maltodekstrin1\% & $17,27 \pm 0,69^{\mathrm{b}}$ & $14,71 \pm 0,26^{\mathrm{a}}$ & $2,55 \pm 0,89^{\mathrm{b}}$ \\
Maltodekstrin2\% & $15,56 \pm 0,32^{\mathrm{a}}$ & $15,30 \pm 0,35^{\mathrm{a}}$ & $0,26 \pm 0,65^{\mathrm{a}}$ \\
Tanpa pembekuan & $19,14 \pm 0,11^{\mathrm{c}}$ & $19,14 \pm 0,11^{\mathrm{b}}$ & $0,00 \pm 0^{\mathrm{a}}$ \\
\hline
\end{tabular}

Keterangan: Data merupakan hasil rata-rata dari 3 ulangan dan angka diiukuti oleh huruf abjad yang berbeda menunjukkan perbedaan nyata berdasarkan uji DMRT $\alpha=5 \%$

Hasil penelitian Topaloglu (2015) menghasilkan kadar air lebih tinggi dengan konsentrasi maltodekstrin $7,5 \%$, yaitu menghasilkan kadar air sebesar $18 \%$. Maltodekstrin bersifat higroskopis yang mudah mengikat air sehingga menyebabkan bahan memiliki daya larut dan daya serap yang tinggi terhadap air. Kohajdová et al. (2009) menyatakan bahwa molekul maltodekstrin tersusun atas gugus hidroksil yang dapat mengikat air dalam jumlah besar. Gugus hidroksil yang mengikat molekul air dapat menyebabkan molekul air berada dalam granula maltodekstrin sehingga air tidak bersifat bebas. Perubahan kandungan kadar air setelah penyimpanan beku dapat disebabkan oleh kristal es yang terbentuk selama pembekuan dan berdampak pada penurunan daya ikat air (water holding capacity) gluten ketika adonan thawing kembali. Gluten merupakan protein utama dalam tepung terigu yang terdiri dari gliadin dan glutenin dan sekitar $30 \%$ asam amino gluten adalah hidrofobik.

Penurunan kemampuan gluten untuk mengikat air mengakibatkan air terlepas saat thawing sehingga kadar air roti dari adonan beku lebih rendah daripada tanpa pembekuan. Penelitian Topaloglu (2015), kadar air menurun karena penggunaan jumlah maltodekstrin meningkat, sekitar 18 dan 16\% pada hari ke-0 dan ke-7. Selain itu, hasil ini juga mengonfirmasi penelitian Pycia et al. (2018) yang menggunakan metode analisis farinografi untuk mengetahui pengaruh penambahan maltodekstrin (2-8\%) pada $100 \mathrm{~g}$ adonan pada struktur adonan. Penambahan maltodekstrin berpengaruh terhadap penyerapan air tepung triticale. Pada tepung yang ditambahkan MLS, nilai rata-rata kadar air lebih rendah sebesar $9,2 \%$ dibandingkan dengan sampel kontrol. 


\section{Kadar abu roti manis}

Hasil penelitian menunjukkan bahwa penambahan maltodekstrin berpengaruh tidak signifikan terhadap kadar abu roti manis (Tabel 7). Kadar abu roti manis pada penelitian ini yaitu antara 1,36$1,44 \%(b / b)$, hasil ini lebih tinggi dari penelitian sebelumnya yaitu Hardoko et al. (2010) yang menghasilkan roti tawar dari substitusi ubi ungu dan penambahan emulsifier dengan kadar abu 0,81 sampai $0,93 \%$, dan hasil dalam penelitian ini lebih kecil dibandingkan dengan kadar abu roti hasil penelitian Balarabe et al. (2017) yaitu sebesar $6,46 \%$. Kadar abu berhubungan dengan kandungan mineral yang terdapat dalam suatu bahan.

\section{Viabilitas yeast}

Penambahan maltodekstrin $1 \%$ efektif untuk mengurangi jumlah yeast yang mati selama pembekuan 10 hari yaitu sebesar $\pm 2,4 \times 10^{6} \mathrm{CFU} / \mathrm{g}$ (Tabel 8). Penambahan maltodekstrin yang semakin banyak $(2 \%)$ secara signifikan dapat mengurangi jumlah ragi yang mati sebesar $\pm 0,7 \times 10^{6} \mathrm{CFU} / \mathrm{g}$, sedangkan adonan tanpa penambahan maltodekstrin viabilitas yeast roti manis turun sebesar $3,12 \times 10^{6}$ $\mathrm{CFU} / \mathrm{g}$. Penambahan maltodekstrin berpengaruh signifikan terhadap jumlah ragi yang hidup setelah pembekuan $(P<0,05)$. Analisis viabilitas yeast mengindikasikan jumlah yeast yang hidup selama penyimpanan beku dari hari ke-0 hingga hari ke-10. Jumlah ragi yang mati tertinggi setelah pembekuan 10 hari yaitu pada sampel tanpa penambahan maltodekstrin sebesar $\pm 3,12 \times 10^{6} \mathrm{CFU} / \mathrm{g}$. Hal ini karena penambahan maltodekstrin dapat membatasi proses difusi molekuler sehingga dapat mengurangi pengaruh dari fluktuasi suhu pada makanan beku. Selain itu, maltodekstrin juga sangat penting untuk mengontrol pelelehan es dan rekristalisasi pada adonan selama penyimpanan beku (Sze-Yin dan Lai-Hoong, 2013).
Jumlah sel hidup pada sampel tanpa penambahan maltodekstrin mengalami penurunan secara signifikan $(P<0,05)$ setelah penyimpanan beku 10 hari. Hal ini dikarenakan proses pembekuan dapat merusak membran plasma sehingga sel mengalami inaktivasi parsial dan kematian (de la Cruz-Gavia et al., 2018). Selain itu, proses fermentasi yang lebih lama dan volume roti yang lebih kecil juga menyebabkan sel ragi rusak dan kehilangan kemampuan untuk produksi gas. Fluktuasi suhu selama penyimpanan dan transportasi juga dapat menyebabkan peningkatan ukuran kristal es dan memperburuk kerusakan ragi beku (Shi et al., 2013).

Berdasarkan hasil penelitian ini, maltodeksrin dapat bekerja sebagai krioprotektan yang cocok diaplikasikan pada pembuatan roti meltode adonan beku. Penambahan maltodekstrin dapat mencegah kematian ragi karena sifat maltodekstrin dapat digunakan mengontrol terbentuknya kristal es selama penyimpanan beku. Hasil temuan ini juga sejalan dengan Paulik dan Jekle (2019) yang menyatakan bahwa aplikasi maltodekstrin memungkinkan adanya pengaruh dalam pengendalian pembentukan gas pada adonan. Hasil penelitian ini menunjukkan bahwa penambahan maltodekstrin adalah alternatif yang layak untuk memperbesar tingkat kelangsungan hidup ragi pada adonan beku.

\section{Organoleptik roti manis}

Penambahan maltodekstrin dengan waktu pembekuan yang berbeda tidak berpengaruh nyata $(P>0,05)$ terhadap sifat organoleptik roti manis dari segi kesukaan terhadap rasa, tekstur dan kesukaan secara keseluruhan. Perlakuan maltodekstrin sebagai cryoprotectant (Maltodekstrin $0 \%$, Maltodekstrin $1 \%$, dan Maltodekstrin 2\%) menghasilkan roti dengan rasa yang cukup disukai (skor 2,7-3,6) (Gambar 2).

Tabel 7. Kadar abu roti manis di awal dan akhir pembekuan

\begin{tabular}{lccc}
\hline \multirow{2}{*}{ Perlakuan } & & Kadar Abu (\%) & Selisih \\
\cline { 2 - 4 } & Hari ke 0 & Hari ke 10 & $0,07 \pm 0,06^{\mathrm{a}}$ \\
\hline Maltodekstrin 0\% & $1,43 \pm 0,08^{\mathrm{a}}$ & $1,36 \pm 0,03^{\mathrm{a}}$ & $0,06 \pm 0,06^{\mathrm{a}}$ \\
Maltodekstrin 1\% & $1,43 \pm 0,08^{\mathrm{a}}$ & $1,36 \pm 0,03^{\mathrm{a}}$ & $0,05 \pm 0,06^{\mathrm{a}}$ \\
Maltodekstrin 2\% & $1,41 \pm 0,08^{\mathrm{a}}$ & $1,36 \pm 0,03^{\mathrm{a}}$ & $0,00 \pm 0^{\mathrm{a}}$ \\
Tanpa pembekuan & $1,44 \pm 0,06^{\mathrm{a}}$ & $1,44 \pm 0^{\mathrm{b}}$ & ${ }^{\mathrm{b}}$ \\
\hline
\end{tabular}

Keterangan: Data merupakan hasil rata-rata dari 3 ulangan dan angka diiukuti oleh huruf abjad yang berbeda menunjukkan perbedaan nyata berdasarkan uji DMRT $\alpha=5 \%$

Tabel 8. Viabilitas yeast di awal dan akhir pembekuan

\begin{tabular}{|c|c|c|c|}
\hline \multirow{2}{*}{ Perlakuan } & \multicolumn{3}{|c|}{ Yeast $\left(\times 10^{6} \mathrm{CFU} / \mathrm{g}\right)$} \\
\hline & Hari ke $0\left(10^{6}\right)$ & Hari ke $10\left(10^{6}\right)$ & Selisih \\
\hline Maltodekstrin $0 \%$ & $5,2^{a}$ & $2,1^{\mathrm{a}}$ & $3,12^{d}$ \\
\hline Maltodekstrin $1 \%$ & $5,0^{\mathrm{ab}}$ & $2,6^{a}$ & $2,4^{\mathrm{c}}$ \\
\hline Maltodekstrin $2 \%$ & $3,5^{\mathrm{a}}$ & $2,8^{a}$ & $0,7^{\mathrm{b}}$ \\
\hline Tanpa pembekuan & $5,5^{\mathrm{b}}$ & $5,5^{b}$ & $0,0^{\mathrm{a}}$ \\
\hline
\end{tabular}

Keterangan: Data merupakan hasil rata-rata dari 3 ulangan dan angka diiukuti oleh huruf abjad yang berbeda menunjukkan perbedaan nyata berdasarkan uji DMRT $\alpha=5 \%$ 


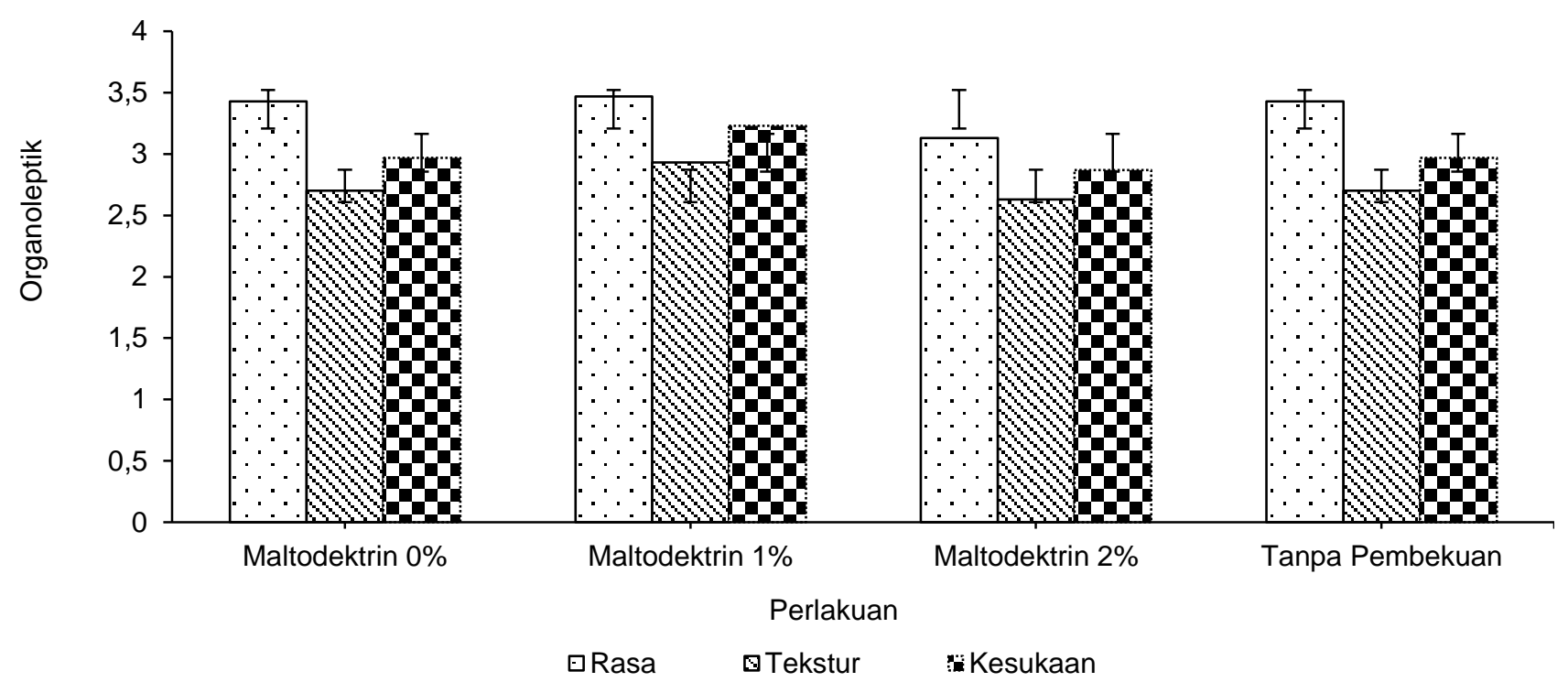

Gambar 2. Karakteristik organoleptik roti manis setelah penyimpanan beku

Maltodekstrin merupakan senyawa hasil hidrolisis pati yang mempunyai tingkat kemanisan rendah, sehingga penggunaan maltodekstrin sebagai krioprotektan tidak memengaruhi rasa roti. Tekstur roti manis setelah penyimpanan beku selama 10 hari menurut panelis memiliki tekstur yang cukup disukai. Maltodekstrin dapat berfungsi sebagai bahan tambahan pangan yang dapat melindungi bahan dari kerusakan. Hal ini sesuai dengan penelitian Topaloglu (2015), setelah 7 hari penyimpanan produk, kekerasan meningkat sekitar $67 \%$ dikarenakan meningkatnya hilangnya kandungan air. Penambahan maltodekstrin menghasilkan roti dengan tekstur cukup disukai yang diwakili oleh nilai dengan range 3 . Hal ini disebabkan maltodekstrin dapat melindungi ragi selama disimpan dalam suhu beku agar tidak rusak dan juga melindungi protein gluten dari kerusakan. Sifat tersebut memberikan tekstur yang kenyal pada roti manis yang dihasilkan sehingga memberikan kesan lembut ketika digigit maupun dikunyah.

\section{KESIMPULAN}

Penelitian ini dapat disimpulkan bahwa konsentrasi maltodekstrin berpengaruh nyata terhadap jumlah khamir yang hidup setelah pembekuan yang berpengaruh terhadap karakteristik lain seperti volume pengembangan, tekstur, dan crumb roti. Penggunaan maltodekstrin $2 \%$ dari total berat adonan dalam formulasi frozen dogh dapat meningkatkan potensi perlindungan ragi pada adonan selama 10 hari penyimpanan. Hal ini menunjukkan maltodekstrin bekerja lebih efektif pada adonan dengan tepung berprotein tinggi. Meski demikian studi lebih lanjut mengenai pengaruh maltodekstrin masih perlu dilakukan lebih detail terhadap protein.

\section{DAFTAR PUSTAKA}

Abd-El-Khalek MH. 2020. Production of ready-tobake whole grain barley cake mix with improved quality. Asian Food Sci J 18: 24-33. DOI: 10. 9734/afsj/2020/v18i330219.

Arendt EK, Morrissey A, Moore MM, Dal Bello F. 2011. Gluten-free breads. In Arendt EK, Dal Bello $F$ (Eds.). Gluten-free cereal products and beverages. 289-304. Academic Press, Amsterdams. DOI: 10.1016/B978-012373739-7.50015-0.

Anggraeni MC, Nurwantoro, Abduh SBM. 2017. Sifat fisikokimia roti yang dibuat dengan bahan dasar tepung terigu yang ditambah berbagai jenis gula. J Aplikasi Teknol Pangan 6: 52-56. DOI: 10.17728/jatp.214.

Ayustaningwarno F. 2014. Teknologi Pangan: Teori Praktik dan Aplikasi. 75. Graha IImu, Yogyakarta.

Balarabe MM, Mohammed SSD, Orukotan A. 2017. Physico-chemical analysis and sensory evaluation of bread produced using different indigenous yeast isolates. Sci World J 12: 33-37.

[BPS] Badan Pusat Statistik. 2020. Ringkasan Eksekutif Pengeluaran dan Konsumsi Penduduk Indonesia. Badan Pusat Statistik, Indonesia.

Chandralekha A, Tavanandi AH, Amrutha N, Hebbar HU, Raghavarao KSMS, Gadre R. 2016. Encapsulation of yeast (Saccharomyces cerevi- 
ciae) by spray drying for extensionof shelf life. Drying Technol 34: 1307-1318. DOI: 10.1080/ 07373937.2015.1112808.

Damat D, Tain A, Handjani H, Khasanah U. 2017. Mikroskopi dan sifat organoleptik kue kering fungsional dari pati garut (Maranta arundinaceae L.) termodifikasi. J Aplikasi Teknologi Pangan 6: 185-189. DOI: 10.17728/jatp.266.

de la Cruz-Gavia A, Pérez-Alonso C, Barrera-Díaz CE, Alvarez-Ramírez J, Carrillo-Navas $\mathrm{H}$, Guadarrama-Lezama AY. 2018. Survival of Saccharomyces cerevisiae microencapsulated with complex coacervate after freezing process. Food Hydrocolloid 82: 45-52. DOI: 10.1016/j. foodhyd.2018.03.045.

Eduardo M, Svanberg U, Ahrné L. 2016. Effect of hydrocolloids and emulsifiers on the shelf-life of composite cassava-maize-wheat bread after storage. Food Sci Nutr 4: 636-644. DOI: 10. 1002/fsn3.326.

Ghoshal G, Shivhare US, Banerjee UC. 2016. Thermo-mechanical and micro-structural properties of xylanase containing whole wheat bread. Food Sci Hum Wellness 5: 219-229. DOI: 10.1016/j. fshw.2016.09.001.

Hardoko, Hendarto L, Siregar TM. 2010. Pemanfaatan ubi jalar ungu (Ipomea batatas L. Poir) sebagai pengganti sebagian tepung terigu dan sumber antioksidan pada roti tawar. J Teknol Industri Pangan 21: 25-32.

Harnkarnsujarit N, Charoenrein S, Roos YH. 2012. Microstructure formation of maltodextrin and sugar matricesin freeze-dried systems. Carbohydr Polym 88: 734-742. DOI: 10.1016/j. carbpol.2012.01.028.

Honary S, Zahir F. 2013. Effect of zeta potential on the properties of nano-drug delivery systems-a review (Part 1). Trop J Pharm Res 12: 255-264. DOI: 10.4314/tjpr.v12i2.19.

Imami RH, Sutrisno A. 2018. Pengaruh proporsi telur dan gula serta suhu pengovenan terhadap kualitas fisik, kimia, dan organoleptik pada bolu bebas gluten dari pasta ubi kayu (Manihot esculenta). J Pangan Agroindustri 6: 89-99. DOI: 10.21776/ub.jpa.2018.006.03.10.

Kohajdová Z, Karovičová J, Schmidt Š. 2009. Significance of emulsifiers and hydrocolloids in bakery industry. Acta Chimica Slovaca 2: 46-61.

Kondakci T, Ang AMY, Zhou W. 2015. Impact of sodium alginate and xanthan gum on the quality of steamed bread made from frozen dough. Cereal Chem 92: 236-245. DOI: 10.1094/C CHEM-03-14-0036-R.
Leray G, Oliete B, Mezaize S, Chevallier S, de Lamballerie M. 2010. Effects of freezing and frozen storage conditions on the rheological properties of different formulations of nonyeasted wheat and gluten-free bread dough. J Food Eng 100: 70-76. DOI: 10.1016/j.jfoodeng. 2010.03.029.

Lopulalan CGCH, Mailoa M, Sangadji D. 2013. Kajian Formulasi Penambahan Tepung Ampas Tahu terhadap Sifat Organoleptik dan Kimia Cookies [Skripsi]. Maluku: Fakultas Pertanian, Universitas Pattimura.

Maity T, Raju PS, Bawa AS. 2011. Effect of hydrocolloids on quality of frozen-thawed vegetable curry. Food Bioproc Technol 5: 2618-2622. DOI: 10.1007/s11947-011-0605-8.

Mandala I, Karabela D, Kostaropoulos A. 2007. Physical properties of breads containing hydrocolloids stored at low temperature. I. Effect of chilling. Food Hydrocolloid 21: 13971406. DOI: 10.1016/j.foodhyd.2006.11.007.

Momose $\mathrm{Y}$, Matsumoto R, Maruyama A, Yamaoka M. 2010. Comparative analysis of transcriptional responses to the cryoprotectants, dimethyl sulfoxide and trehalose, which confer toleranceto freeze-thaw stress in Saccharomyces cerevisiae. Cryobiology 60: 245-261. DOI: 10. 1016/j.cryobiol.2010.01.001.

Nopianti R, Huda N, Noryati I, Fazilah A, Easa AM. 2012. Cryoprotective effect of low-sweetness additives on protein denaturation of thread fin bream surimi (Nemipterus spp.) during frozen storage. CYTA-J Food 10: 243-250. DOI: 10. 1080/19476337.2011.639033.

Noroul AZ, Ma'aruf AG, Sahilah AM, Mohd Khan A, Wan Aida WM. 2013. A new source of Saccharomyces cerevisiae as a leavening agent in bread making. Int Food Res J 20: 967-973.

Paulik S, Jekle M. 2019. Novel approach to investigate the mechanical properties of crumb matrix during storage - Re-engineering of gasfree crumb pellets. Food Chem 288: 333-340. DOI: 10.1016/j.foodchem.2019.03.014.

Phimolsiripol Y, Mukprasirt A, Schoenlechner R. 2012. Quality improvement of rice-based gluten-free bread using different dietary fibre fractions of rice bran. J Cereal Sci 56: 389-395. DOI: 10.1016/j.jcs.2012.06.001.

Pusuma DA, Praptiningsih Y, Choiron M. 2018. Karakteristik roti tawar kaya serat yang disubstitusi menggunakan tepung ampas kelapa. J Agroteknologi 12: 29-42. DOI: 10.19184/j-agt.v1 $2 \mathrm{i} 1.7886$. 
Pyciaa K, Jaworskaa G, Telegaa J, Sudoła I, Kuźniarb P. 2018. Effect of adding potato maltodextrins on baking properties of triticale flour and quality of bread. LWT-Food Sci Technol 96: 199-204. DOI: 10.1016/j.Iwt.2018. 05.039 .

Rathnayake HA, Navaratne SB, Navaratne CM. 2018. Porous crumb structure of leavened baked products. Int J Food Sci 2018: 1-15. DOI: 10.1155/2018/8187318.

Seetapan N, Limparyoon N, Gamonpilas C, Methacanon P, Fuongfuchat A. 2015. Effect of cryogenic freezing on textural properties and microstructure of rice flour/tapioca starch blend gel. J Food Eng 151: 51-59.

Shi K, Yu H, Lee T-C. 2013. A novel approach for improving yeast viability and baking quality of frozen dough by adding bio-genic ice nucleators from Erwinia herbicola. J Cereal Sci 57: 237243.
Sze-Yin S, Lai-Hoong C. 2013. Effects of maltodextrin and trehalose on the physical properties of chinese steamed bread made from frozen doughs. Int Food Res J 20: 1529-1535.

Topaloglu T. 2015. Evaluation of Valution of the Effects of Maltodextrine and Microfluidization onthe Rheological and Textural Properties of Cookie and Cookie Dough [Thesis]. Ankara: Department of Engineering, Middle East Technical University.

Witczak M, Korus J, Ziobro R, Juszczak L. 2010. The effects of maltodextrins on gluten-free dough and quality of bread. J Food Eng 96: 258-265. DOI: 10.1016/j.jfoodeng.2009.07.022.

Yamashita C, Chung MMS, dos Santos C, Mayer CRM, Moraes ICF, Branco IG. 2017. Microencapsulation of an anthocyanin-rich blackberry (Rubus spp.) by-product extract by freezedrying. LWT-Food Sci Technol 84: 256-262. DOI: 10.1016/j.Iwt.2017.05.063. 